\title{
TECHNICAL EFFICIENCY OF FARMS \\ IN POLAND ACCORDING \\ TO THEIR SIZES AND TYPES
}

\author{
ADAM HENRYK KAGAN
}

\begin{abstract}
The article presents technical efficiency of the use of production resources for the research sample of the Polish FADN, representing the general population of agricultural holdings, representing over $90 \%$ of domestic commercial production. The impact of the size of activity measured by the utilised agricultural area and standard output (economic size), and of the production type on the efficiency was examined. In all cases, non-linear relationships were found, and the technical efficiency curve for grouping characteristics based on the size of the activity took the $U$ shape. Therefore, deviations from the shape of these relations observed in numerous studies may result not only from the selection of the measurement method, but also from the lack of representativeness for the entire agrarian structure of researched farms. Assessing the impact of production orientation on technical efficiency without taking into account the diversity of groups in terms of the size of activity, especially with different assignments to different classes of economic size, in many cases may lead to erroneous conclusions.
\end{abstract}

Keywords: farm size, technical efficiency, standard output, production type.

JEL codes: Q12; Q13; Q18.

Mgr inż. Adam Henryk Kagan, Instytut Ekonomiki Rolnictwa i Gospodarki Żywnościowej - Państwowy Instytut Badawczy, Zakład Ekonomiki Gospodarstw Rolnych; ul. Swiętokrzyska 20, 00-002 Warszawa (adam.kagan@ierigz.waw.pl). ORCID iD: 0000-0001-9385-3720. 


\section{Introduction}

The issue of the efficiency of using production factors (production resources) at the technical level depending on the size of agricultural holdings has been the subject of numerous research and scientific publications. Papers based on both foreign and domestic data raising this issue are ambiguous. When using land productivity measured by the value of production per unit of area (partial efficiency), usually the advantage of small agricultural holdings relative to large entities is indicated. If all production factors are taken into account, i.e. the measurement of technical efficiency (total productivity), the obtained research results are more diverse. Different factors which shape the relationships between technical efficiency, land productivity or its efficiency and the size of agricultural holdings are also indicated.

The objective of the study was to determine technical efficiency in the sample representing the majority of agricultural holdings in the country depending on the size of activity and their production type, and to recognise the nature of these relationships. Due to the fact that technical efficiency can play the role of a simplified measure of social efficiency of agricultural holdings, this problem seems to be important not only from the scientific point of view, but also for shaping future agricultural policy. The study omitted allocation efficiency (efficiency after taking into account the prices of all production inputs).

\section{Research on foreign agriculture}

It is assumed that contemporary debate on the impact of the size of agricultural activities on the efficiency of the use of production resources (inputs) was started by Sen (1962). He noticed the reversed dependency between the value of production obtained from 1 ha of utilised agricultural area and the size of the farm, which became a premise for further scientific research on this issue, but also had an impact on agricultural policy in some countries. He also noted that profitability of farms increases along with their size. However, when taking into account opportunity costs of family labour at the level of wages and salaries received in the national economy, the majority of Indian agriculture was unprofitable due to the agrarian structure and the share of small agricultural holdings. He ascribed the reasons for this phenomenon to the imperfections of the labour market. Higher production value per unit of area in small agricultural holdings has become the basis for recognising their advantage over large farms.

Similar conclusions were reached by Carter (1984) who proved a strong negative relationship between farm size and production value per unit of area. On the basis of data for Indian agriculture from 1966-1972, he calculated that land productivity decreased by almost $40 \%$ when the farm size was doubled, and after correction due to the impact of soil quality by $20 \%$. At the same time, he noted the economic inefficiency of small agricultural holdings due to the use of much larger inputs per unit of production, in particular labour. 
Based on the analysis of numerous empirical studies, Binswanger, Deininger and Feder (1995) also confirmed the advantage in terms of production value per hectare of small agricultural holdings (though not the smallest) over large ones. They also found that these differences increased in regions of the world with wide land availability (in Latin America, in selected African countries), and were smaller in Asia where the spread between the ownership of utilised agricultural area was the smallest. They also noted that the most productive group were not the smallest farms, but the next group in terms of size providing full-time employment of the owner.

Srinivasan (1972) stated that the difference in the level of inputs observed on farms of various sizes is the result of a state of uncertainty and the level of aversion to the productive risk of the farm manager. Similarly, Barrett (1996) explained this phenomenon by the need to ensure food security of own household in conditions of price uncertainty. According to their conclusions, high level of risk (the need to meet basic food needs) in small agricultural holdings results in the excessive use of production inputs, especially labour.

Feder (1985) and Eswaran and Kotwal (1985) noticed that it is not the price distortions of agricultural raw materials but the availability of credit (capital market) and the distortion of the labour market and land that can significantly modify farm productivity, and the relationship between yield and production volume may have non-linear character. The same conclusions were reached by Carter and Kalfayan who, based on a theoretical model, proved that with the imperfections of the labour market and capital, the relationship between the size of an agricultural holding and its productivity is non-linear, and in addition takes the $\mathrm{U}$ shape (Binswanger et al., 1995).

In the 1990s, Johnson and Ruttan (1994) and Peterson and Kislev (1991) proved the lack of a beneficial effect of farm size on input productivity. In addition, they stated that while positive economic effects of scale can be observed in other branches, in agriculture, with some exceptions, this principle does not work (effects are at most proportional). The increase in wages in non-agricultural sectors and mechanisation caused changes in the size of farms and the substitution of labour with capital. Agriculture is still mainly based on the work of the owners and their families (own labour inputs), so family labour resources strongly limit the increase in farm size. Similarly, Binswanger and Rosenzweig (1986) rejected the impact of the benefits of the economic scale of production on the increase in farm size in agriculture. They claimed that other factors cause changes, especially in developed countries. In their opinion, despite technical and technological changes taking place, family farms show an advantage at the technical level.

De Janvry and Sadoulet (2006) also came to the conclusion that smaller agricultural holdings use productive resources (mainly land) more efficiently, and the technology they use is more labour-intensive. In traditional agriculture where labour is the main variable, they achieve higher yields than larger farms which use employed labour. However, they pointed out lower payment for labour obtained in 
small agricultural holdings, and at the same time that the consumption side of the household in such entities is reduced to a compromise between income (consumption) and leisure time.

Chen, Huffman and Rozelle (2011) pointed to differences in soil fertility and location of land as the main driver of productivity decline along with the increase in the size of agricultural holdings in China. According to their research, taking this parameter into account meant that production was proportional to the size of the farm. However, they used the data only for the population in which the average area of land did not exceed $10 \mathrm{Mu}$ (about $0.7 \mathrm{ha}$ ). They indicated the impact of soil quality as the main argument for not changing China's agrarian policy towards reducing the size of already relatively small farms.

Barrett, Bellemare and Hou (2010), who researched agricultural holdings in Madagascar in 2002, did not confirm the impact of soil quality. Looking for explanations for the reversed dependency between technical efficiency and farm size, they took into account a number of parameters related to soil fertility, including: content of micronutrients, organic matter, mechanical composition and soil reaction. They explained the above-mentioned reversed dependency with the impact of market imperfections, while in the case of soil quality they recognised that it is not a feature that affects the characterised dependency to a statistically significant extent.

Fan and Chan-Kang (2005) noted that after a period of accelerated industrialisation and urbanisation in many Asian countries in the 1990s, there was a change in the attitude towards small agricultural holdings, which can be summarised as a return to the statement "small is beautiful". While earlier their functioning was often recognised as an obstacle to the modernisation of countries, thanks to the diversification of the structure of commodity production and intensity, they could obtain comparative advantages over larger farms, at the same time producing in a more environmentally friendly way. The observed reversed dependency between farm size and land productivity was conditioned by many factors: land use intensity, soil fertility and management skills of the owners. In addition, they pointed out that the sustainability of production on small farms is currently being questioned by the ongoing process of trade liberalisation which places small farms in an unfavourable situation.

Kagin, Taylor and Yúnez-Naude (2016), based on panel data from 2003-2008 relating to Mexican agriculture, confirmed the negative relationship between land productivity and farm size. On the basis of the results obtained, they noted that this also translates into technical efficiency, i.e. taking into account the total production inputs. Thus, small Mexican farms, despite globalisation processes and transformation of agricultural supply chains and sales of agricultural raw materials, show high flexibility in adapting to changes in the environment, and at the same time competitiveness.

Henderson and Isaac (2017) also drew attention to the issue of transaction costs. They stated that the direction of changes in agricultural supply chains and product 
sales does not affect the reversed dependency between farm sizes and their technical efficiency. Rising transaction costs will increasingly affect the allocation efficiency and deployment of production resources.

Gautam and Ahmed (2019) studying the technical efficiency of agricultural holdings in Bangladesh in 2000-2008 came to similar conclusions. In this country, smaller farms had higher technical efficiency compared to larger farms. However, they noticed that over time the force of the relationship decreases, which they explained with the technological changes and especially the process of mechanisation of production. Thus, they noted that the advantages of small agricultural holdings are weakening at the level of technical use of inputs, and the pace of this phenomenon depends on the scope of introducing new technological solutions in agriculture.

In turn, Ansoms, Verdoodt and Van Ranst (2008) observed a strongly negative impact of farm size on land productivity in Rwandan agriculture. Their observation that extreme land scarcity in this country leads to over-exploitation of land by very small agricultural holdings is interesting. As a consequence, the fragmented agrarian structure in the conditions of labour market imperfections in this country brings adverse environmental effects. However, several other studies have shown that the reversed relationship between the value of production from a unit of area and the size of a farm disappears if labour inputs and their cost at market level are taken into account (Ali and Deininger 2015).

Bakucs, Latruffe, Fertő and Fogarasi (2010), examining technical efficiency of Hungarian agriculture, stated that since the integration with the EU, the trend of decline in technical efficiency in this sector has been reversed. Diversity of efficiency was largely conditioned by the soil quality and the legal form of the farm. Entities operating in the form of companies (with employed labour) have proved to be more technically efficient than individual (family) farms, with the simultaneous positive impact of higher labour inputs per unit of land area. In their opinion, this could suggest a shortage of labour in Hungarian agriculture. Multidirectional and specialised farms were characterised by a higher level of efficiency. Among specialised farms, the advantage of farms with livestock production over plant production was observed.

Baležentis, Kriščiukaitienė and Baležentis (2014) came to slightly different conclusions using panel data from 2004-2009 for Lithuanian family farms. In their study, the increase in farm size led to a slight increase in technical efficiency, although for units over 400 ha they also observed an increase in the variability of results. At the same time, they emphasised the impact of production orientation. Farms specialised in livestock production were characterised by a higher level of efficiency in relation to multidirectional farms, and the latter in relation to those with plant production.

Bojneca and Latruffe (2013) made similar conclusions on the basis of data from 2004-2006 for Slovenian farms. They established a positive relationship between technical efficiency and the size of agricultural holdings measured by: area (ha), 
economic size (ESU) and livestock headage. However, while the orientation of production to granivores allowed obtaining statistically significantly higher technical efficiency, it was negatively affected by farming of grazing animals.

Alvarez and Arias (2004) examining Spanish dairy farms in 1993-1998 also obtained a positive relationship between the size of activity and technical efficiency. Sheng, Zhao, Nossal and Zhang (2014) came to similar conclusions on the basis of data from 1977-1978 and 2006-2007 referring to Australian agricultural holdings. However, they recognised that the positive impact occurs indirectly, assigning a much greater role to technological diversity which, in their opinion, resulted from the volume of production.

Helfand and Taylor (2018), by measuring efficiency using partial indicators for agricultural holdings in Brazil in 1985-2016, confirmed that land productivity in all regions decreases along with an increase in production scale, while labour productivity increases. This phenomenon deepened over time, and the differences between the groups determined on the basis of utilised agricultural area increased. The overall efficiency of the use of inputs in the layout took on a shape similar to the letter U. The largest agricultural holdings, i.e. those with 500-5000 ha, were characterised by the highest level of efficiency. However, while in 1985 this curve was strongly flattened and no statistically significant intergroup differences were shown, since 1996 the efficiency of the largest agricultural holdings has proven to be statistically significantly higher than that of the smallest ones (from 0 to $5 \mathrm{ha}$ ), similarly to that of other groups. In 2006, a flattening to the right of the letter U was noted, which was the result of a higher efficiency of the second group in terms of size, i.e. farms with an area of 5 to 20 ha, relative to the ones with the smallest area.

Research results obtained by Bhatt and Bhat (2014) also confirmed the above theoretical assumptions of Feder, Carter and Kalfayan regarding the relationship between the size of agricultural activity measured by utilised agricultural area and technical efficiency. The characteristic shape of the graphic curve in the form of the letter $U$ was obtained on the basis of data from 2013-2014 for agricultural holdings with an area from 0 to 27 acres $(10 \mathrm{ha})$ from the Jammu and Kashmir region in India.

\section{Research on Polish agriculture}

Van Zyl, Miller and Parker (1996) claimed that the technical and economic advantage of large agricultural holdings in Poland is not reflected in reality. However, in the analytical part, they used only the data of individual agricultural holdings from 1993 separating three groups, including entities with more than 15 ha. They proved that farms up to 5 ha (group with the smallest area) from a technical point of view use inputs more efficiently compared to other groups, in particular the largest farms (with an area of over $15 \mathrm{ha}$ ). Much smaller differences, though also in favour of small agricultural holdings, were observed by them in the case of efficiency of production scale, while farms with an area of 10-15 ha were characterised by the highest level of allocation efficiency. These researchers were surprised by the rela- 
tively small differences between groups, but based on the results obtained, they formulated quite far-reaching conclusions regarding the direction of agrarian policy in Poland. In their opinion, the proper form of restructuring of state-owned agricultural holdings in the analysed period was their division into small units which would not lead to a decrease in agricultural productivity, and could bring positive effects. They considered them to be an increase in employment in agriculture and at the same time overcoming capital restrictions. An important conclusion was also the proposal to stop providing state support for activities aimed at increasing the scale of production among small and medium-sized individual agricultural holdings (concentration processes).

Similar results were obtained by Munroe (2001) who proved lower efficiency on farms of over 15 ha compared to other area groups. However, she also noted significant impact of other characteristics, such as the owner's experience (farmer's age) and the level of farm modernisation.

Lerman (2002), measuring technical efficiency of individual agricultural holdings slightly later (data from 2000), obtained different results. He noted that along with the increase in utilised agricultural area, productivity of land decreased, but to a small extent, while labour productivity increased significantly. The graphic curve presenting the dependence of technical efficiency on the utilised agricultural area took the classic U shape. In his opinion, the most technically efficient group in Poland were entities with an area of over 100 ha, i.e. large-scale agricultural holdings. Next in terms of the efficiency level were the smallest farms, i.e. with an area of 0-1 ha and with 60-100 ha. The lowest indicator was recorded in the case of medium-sized farms, i.e. those with 7-20 ha. Lerman claimed that the improvement in the technical efficiency of Polish agricultural holdings requires the creation of large-scale agricultural holdings, but this will lead to a reduction in employment in agriculture, which is why he attributed an important role to the creation of nonagricultural jobs.

The differences between the results obtained by Van Zyl, Miller and Parker and Munroe and the results of Lerman are very interesting. It is hard to assess to what extent they were caused by the time factor and changes in market conditions (e.g. changes in the cost of capital, labour market), and to what extent by the differences in the structure of the research sample. At the same time, it should be emphasised that 6 farms over 100 ha and 11 from the 60-100 ha range participated in Lerman's study. He also did not verify whether the intergroup differences were statistically significant.

These doubts were not dispelled by the results of research conducted by Latruffe, Balcombe, Davidov and Zawalińska (2005) on the impact of production specialisation on technical efficiency and production scale. It confirmed non-linear relationships, and moreover, the results obtained by Lerman for farms with livestock and partially plant production were data only from 2000 (data from the researched 1996 was omitted). The authors emphasised extremely low numbers in the smallest groups of areas, which resulted from the selection of the research sample. For 
methodological reasons, the indicated higher technical efficiency of farms with livestock production in relation to plant production also raises doubts. Using the Data Envelopment Analysis (DEA), it is impossible to compare the results obtained in two separate models where there is a high probability of a different course of the limiting (reference) curve.

Sulewski (2008) confirmed the results of van Zyl and others based on data from 100 family farms from 2005, i.e. a significant advantage in terms of technical efficiency of farms with the smallest area (up to 10 ha in the study) and some stabilisation of the average indicator for agricultural holdings above 15 ha (the lowest result was obtained by farms with an area of 15-20 ha and over 50 ha). In his study, however, the scale efficiency was strongly and positively correlated with farm size.

On the basis of data for the population of farms of natural persons of the Polish FADN ${ }^{1}$ from 2006-2008, Czyżewski and Smędzik (2010) obtained results in which farms with an area not exceeding 5 ha and with an average size (10-20 ha) were characterised by the highest technical efficiency. The lowest indicator was obtained by the largest farms, i.e. those with 50 ha of utilised agricultural area and more. In addition, they observed that horticulture farms and farms with permanent crops had a higher level of technical efficiency, and the lowest - farms of mixed type. Smędzik (2010) also included farms of with granivores in the first group. However, the results of these studies were methodically biased which resulted from the use of averaged values of inputs and effects for individual groups as input data included in the models, rather than unit data.

Syp, Kagan and Osuch (2018) showed higher technical efficiency of farms with pigs in the local dimension (Lubelskie Province) over those with plant production. However, this sample included only large agricultural holdings, and groups separated depending on the orientation of production significantly differed in size of activity, which did not allow for generalisation of results to the entire population. This possibility was provided by Hockmann's research (2015) using the author's dynamic model for measuring technical efficiency. Research results carried out for panel data from 2004-2007, regardless of the impact of dynamic factors, indicated a higher level of technical efficiency of farms with granivores and grazing animals, and the lowest on farms with field crops and mixed type.

The choice of research method may have a great impact on the results obtained. This fact was pointed out by Marzec and Pisulewski analysing dairy farms in 2001-2004. By using the parametric method (Stochastic Frontier Analysis) for the same empirical data when modifying the production function in one study, they obtained a positive relationship between technical efficiency and the size of the farm measured by the utilised agricultural area (Marzec and Pisulewski, 2013a), and in another study farms with smaller area proved to be more efficient (Marzec and Pisulewski 2013b).

\footnotetext{
${ }^{1}$ Polish Farm Accountancy Data Network.
} 


\section{Research method and sample characteristics}

Technical efficiency calculated using the DEA was used in the research. This solution was supported by the fact that the study covered both large agricultural holdings of a market nature and small farms producing largely for self-supply, i.e. entities using various production technologies. Despite numerous drawbacks, the DEA is resistant to the diversity of the studied objects in this respect. In addition, it does not require the selection of a production function, which is its advantage over parametric methods (Gorton and Davidova, 2004).

However, the method of determining the optimal technology (efficiency curve) in the DEA may vary. It depends, among others, on the type of assumed effects of the scale of production. In the study, technical efficiency was calculated using the BCC model, i.e. based on the Banker, Charnes and Cooper equation, and thus assuming variable effects of the scale of operations. According to its principles, the optimal technology for entities is determined based on the following equation (Cooper, Seiford and Tone, 2007):

$$
P(x, y)=\left\{x_{j}=>X \lambda_{j}, y_{j}<=Y \lambda_{j}, \lambda_{j}=>0, \sum_{j=1}^{n} \lambda_{j}=1\right\}
$$

where:

$P(x, y)$ - production possibility set in the studied sample,

$x_{j} \quad-$ vector $m$ of inputs in $j$-th entity,

$X \quad$ - input matrix with dimensions $(n * m)$ for all $n$ objects,

$y_{j} \quad-$ vector $s$ of effects in $j$-th entity,

$Y \quad$ - input matrix with dimensions $(n * s)$ for all $n$ objects,

$\lambda_{j} \quad-$ weights which are the linear combination factors (saturation parameters),

$s \quad-$ number of results,

$m \quad-$ number of inputs.

Determination of the production possibility set allows the measurement of the distance between the leaders representing optimal technology and other enterprises. The mathematical record of this operation is as follows (Cooper, Seiford and Zhu 2004):

$$
E\left(x_{j}, y_{j}\right)=\min \left\{\theta: \theta x_{j}, x_{j} \in P(x, y)\right\}
$$


where:

$E(x, y)$ - function of the distance between the point characterising technology of a given farm and the object with the optimal technology (envelope),

$x_{j} \quad-$ vector $m$ of inputs in $j$-th entity,

$y_{j} \quad-$ vector $s$ of effects in $j$-th entity,

$\theta-$ efficiency factor of the object,

$P(x, y)$ - production possibility set,

$s \quad-$ number of results,

$m \quad-$ number of inputs.

In this equation, the value of $\theta$ (multiplier of inputs) determines what multiplicity of inputs should be applied in relation to the optimal solution while maintaining at least the same amount of effect. The minimum value of $\theta$ found determines technical efficiency of a given object which for leaders - standard units - is 1 (Coelli, Prasada Rao, O’Donnell and Battese, 2005).

Determinations of technical efficiency require defining input (inputs) and output (results-effects) parameters. In the conducted research, the sum of plant production (variable code SE1352) and livestock production (variable code SE206) value was taken as the effect. When calculating the parameter - effect, the value of other production (code SE256) was omitted as the activity which is not directly related to the operational activity of the agricultural holding. All forms of budget subsidies were also not taken into account in line with the assumption that these are not elements of technical efficiency of the farm, but compensation instruments of an allocation nature.

The following independent variables were taken as inputs:

- utilised agricultural area (ha) - total area of land used for agriculture, both own and leased, including idle land and fallow (code SE025);

- total labour input (code SE010) expressed in AWU (number of full-time employees);

- fixed assets of a balance nature reduced by own land value (code SE441-SE446);

- intermediate consumption (code SE275) including direct costs and general economic costs associated with operating activities.

The division and assignment of means of production to individual groups of inputs was dictated by their specific features. In the isolation process, different possibilities for their reduction (substitution) and the scope of complementarity were taken into account (Kagan, 2014). The selection of inputs and effects does not differ significantly from the classic approach used by Farrell (1957), so it can be considered canonical.

In order to determine the statistical significance of intergroup differences, the non-parametric Kruskal-Wallis test was used, which was supplemented with a post hoc test - the Dunn's test in a version including the Bonferroni correction.

\footnotetext{
${ }^{2}$ The variable code and its definition used in research conducted by Polish FADN.
} 
In the case of groups for which the distribution differences were not statistically significant the Mann-Whitney test of pairs was additionally used. In such cases, the result of the last test was considered conclusive (Danel, 2016).

The analysis used unit data of all agricultural holdings participating in the Polish FADN in 2016-2017 for which full accounting and production data was compiled in the IERiGŻ-PIB. The choice of research years was dictated by the availability of the most current numerical data and the lack of significant methodological changes. The sample of the Polish FADN consisted mainly of individual farms, but it also included farms of legal persons. In total, they represented a general population of almost 731 thous. agricultural holdings in the country with an economic size expressed in the value of standard output (SO) of at least EUR 4 thous. Thus, the general population was made up of farms representing over $93 \%$ of agricultural standard output in the country, having $85 \%$ of utilised agricultural area and $66.5 \%$ of full-time agricultural workers (Goraj, Osuch, Bocian, Cholewa and Malanowska, 2013). In relation to the entire population of agricultural holdings in the country, only the smallest entities remained outside the field of observation of the Polish FADN. The FADN sample was representative of the general population in terms of economic size, production type and regional location (Bocian, Osuch and Smolik, 2018). However, due to insufficient numbers, the impact of the last feature was omitted later in the study.

Table 1

Research sample, input and value of production in 2016-2017

\begin{tabular}{|c|c|c|c|c|c|}
\hline Detailed list & $\begin{array}{c}\text { Annual work } \\
\text { unit (AWU) }\end{array}$ & $\begin{array}{l}\text { Utilised } \\
\text { agricultural } \\
\text { area (ha) }\end{array}$ & $\begin{array}{c}\text { Intermediate } \\
\text { consumption (PLN) }\end{array}$ & $\begin{array}{l}\text { Adjusted } \\
\text { fixed assets } \\
\text { (PLN) }\end{array}$ & $\begin{array}{c}\text { Production } \\
\text { value (PLN) }\end{array}$ \\
\hline 2017 & \multicolumn{5}{|c|}{$\mathrm{N}=12293$} \\
\hline Mean & 2.1 & 44.8 & $191,647.0$ & $541,885.7$ & $306,096.2$ \\
\hline Median & 1.8 & 24.4 & $85,598.0$ & $344,511.0$ & $149,153.7$ \\
\hline Standard deviation & 3.0 & 114.0 & $674,467.8$ & $963,440.2$ & $870,272.5$ \\
\hline General population & \multicolumn{2}{|r|}{$\mathrm{N}=730902$} & \multicolumn{3}{|c|}{ Average multiplier $=59.46$} \\
\hline 2016 & \multicolumn{5}{|c|}{$\mathrm{N}=12302$} \\
\hline Mean & 2.1 & 45.2 & $191,918.0$ & $542,799.0$ & $287,613.5$ \\
\hline Median & 1.8 & 24.5 & $85,371.0$ & $342,164.5$ & $137,706.2$ \\
\hline Standard deviation & 3.2 & 114.5 & $656,646.8$ & $943,920.6$ & $834,691.9$ \\
\hline General population & \multicolumn{2}{|r|}{$\mathrm{N}=730762$} & \multicolumn{3}{|c|}{ Average multiplier $=59.40$} \\
\hline
\end{tabular}

Source: based on (Floriańczyk, Płonka and Osuch, 2017 and 2018). 
In 2016-2017, on average, one object in the sample represented more than 54 agricultural holdings in the general population (average multiplier). The researched farms were very diverse in terms of the inputs used (especially the feature - intermediate consumption and production value had a high volatility index (Table 1). This was a natural consequence of representing a wide spectrum of entities appearing in the general population. Similar level of variability of individual features in 2016-2017 should be emphasised.

\section{Research results}

The results of measuring technical efficiency indicate very large potential possibility to improve the use of production inputs in both the sample and the general population (Table 2). A classic measure of central tendency - mean at the level of 0.4 indicates that potentially the same effect could be obtained with a $60 \%$ lower level of inputs. On the other hand, the positional measure - median informs that half of the units had even greater reserves in terms of the possibilities to improve technical efficiency. It should be emphasised that the results of measures of central tendencies varied only slightly between the analysed years and when comparing the sample and general population.

Table 2

Technical efficiency in 2016-2017

\begin{tabular}{|c|c|c|}
\hline Results & 2016 & 2017 \\
\hline Range & \multicolumn{2}{|c|}{ Share $(\%)$} \\
\hline $0-0.199$ & 1.4 & 0.9 \\
\hline $0.200-0.399$ & 57.6 & 55.9 \\
\hline $0.400-0.599$ & 33.3 & 34.6 \\
\hline 0.600-0.799 & 5.5 & 6.4 \\
\hline 0.800-0.999 & 1.3 & 1.3 \\
\hline 1.00 & 0.9 & 0.8 \\
\hline Statistical measure & \multicolumn{2}{|c|}{ Value } \\
\hline Mean & 0.400 & 0.409 \\
\hline Median & 0.373 & 0.380 \\
\hline Standard deviation & 0.139 & 0.138 \\
\hline Average general population ${ }^{\mathrm{a}}$ & 0.399 & 0.407 \\
\hline
\end{tabular}

${ }^{a}$ After taking into account the multiplier resulting from the number of farms represented in the general population.

Source: own calculations. 
The distribution of technical efficiency results indicates its slight right-side asymmetry, and for over half of the farms the indicator was in the range of 0.2-0.4. Both in the case of the model for 2017 and 2016, a small number of farms formed the reference curve (it had the value equal to 1 ).

The researched farms were significantly less efficient in terms of the scale of activity. The level of efficiency was higher in 2016 compared to 2017 and amounted to 0.818 on average. A change of the scale of production and adjustment to the optimal size in 2016 in all farms of the research sample could lead to an increase in efficiency by $18.2 \%$ on average, while in the general population by $21.3 \%$. In 2017 , the efficiency of the production scale was lower and a greater difference was found between the classic measure of central tendency in the sample and in the general population.

Analysing the impact of utilised agricultural area on technical efficiency, a non-linear relationship was confirmed (Figure 1). In the layout, in both studied years and irrespective of the measure of central tendency, the changes took the $U$ shape. Farms with the smallest area (less than 2 ha) were characterised by the highest level of technical efficiency of using inputs, then the value of the indicator decreased along with the increase in the area to reach the smallest values in area groups of 10-29.99 ha.

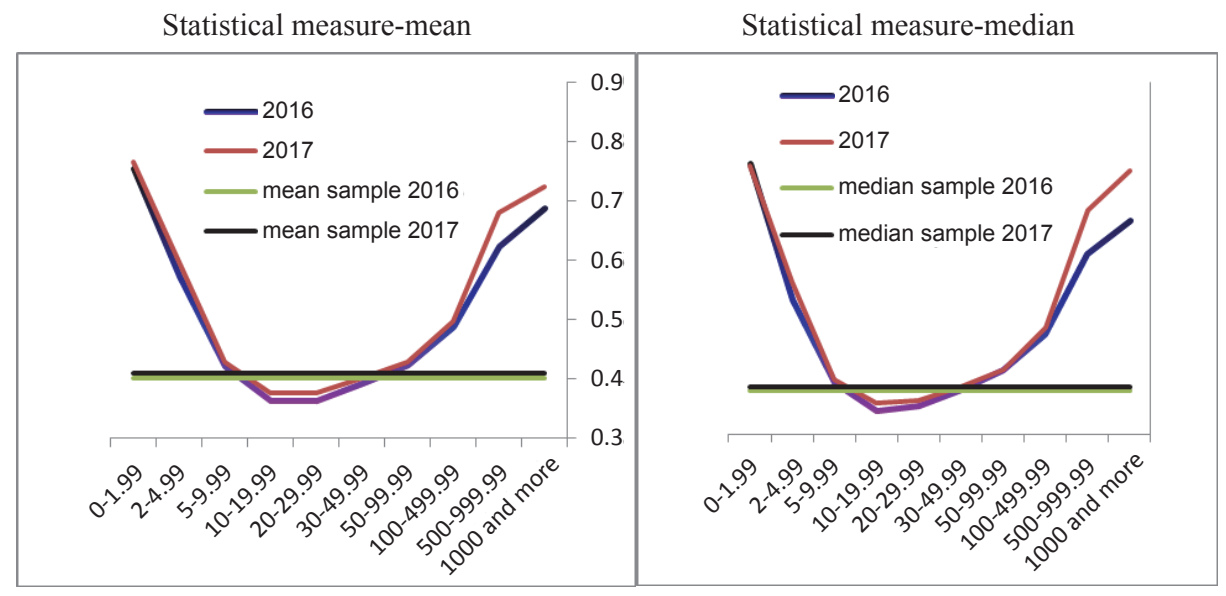

Fig. 1. Technical efficiency in 2016-2017 in groups separated on the basis of utilised agricultural area (ha).

Source: own calculations.

Due to the reversion of the direction of changes, farms with 30 ha and more had a positive relationship between utilised agricultural area and technical efficiency. It should be noted that the second group in terms of the level of this indicator were the largest farms - 1000 ha and more. In this group, similarly to farms with an area of 500-999.99 ha, an increase in efficiency was observed over time (over 2016-2017). 
The conducted Kruskal-Wallis test allowed the rejection of the null hypothesis on the lack of statistical significance of the distribution of the technical efficiency indicator in 2016 and 2017 in groups separated on the basis of utilised agricultural area. ${ }^{3}$ After carrying out the Dunn's test and additional verification for some groups with the Mann-Whitney test, no statistically significant differences in the distribution between farms up to 2 ha (with the smallest area) and the largest, i.e. with 1000 ha and more, i.e. two groups with the highest indicators of central tendency measures, were found (Table 3). There were also no differences in the distribution of the indicator between the group of farms with the largest area and the second group, i.e. in the range of 500 to 999.99 ha, as well as with the lowest value of central tendency measures, i.e. with an area of 10-19.99 ha and 20-29.99 ha.

Table 3

Groups of farms separated on the basis of utilised agricultural area for which differences in technical efficiency distribution turned out to be statistically insignificanta and the median value in 2017

\begin{tabular}{|c|c|c|c|}
\hline \multirow{2}{*}{ Area (ha) } & \multicolumn{3}{|c|}{ Area (ha) } \\
\hline & $0-1.99$ & $10-19.99$ & $500-999.99$ \\
\hline $20-29.99$ & & .353 & \\
\hline 1000 i więcej & 0.750 & & 0.750 \\
\hline
\end{tabular}

${ }^{a}$ In the case of these groups, the null hypothesis was not rejected with a probability of $p>0.05$.

${ }^{\mathrm{b}}$ The median value for the group in the top row is above the line, while for the group in the first column below the line.

Source: own calculations.

Taking into account the economic size of an agricultural holding measured by standard output (SO) as the grouping variable, technical efficiency in the layout took different shape (Figure 2). It decreased with the increase in economic size from the class of EUR 4-7.99 thous. of standard output to the class of EUR 15-24.99 thous. Then a change in the direction of the curve was observed. On farms larger than EUR 25 thous., the analysed indicator increased along with the increase in the size. The level of central tendency measures in classes with SO above EUR 100 thous. (large and very large) was higher than on farms with the smallest economic size (very small).

The slightly different shape of the technical efficiency indicator, on the one hand, is the result of the lack of the smallest entities in the population (farms with the economic size of up to EUR 4 thous.), which are likely to have a much higher indicator than farms of up to EUR 100 thous., and on the other hand, of the nature of the grouping variable. Entities with the smallest area (up to $5 \mathrm{ha}$ ) were often

${ }^{3}$ For 2016 data $\mathrm{H}(9, \mathrm{~N}=12,302)=1498.132 ; p=0.000$, while for 2017 data $\mathrm{H}(9, \mathrm{~N}=12,293)=1385.333$; $p=0.000$. 
characterised by a much higher value of standard production per 1 ha, which resulted in different assignment to the economic size class. Therefore, it can be assumed that in the population of agricultural holdings in the country, taking into account economic size as a measure of farm size, technical efficiency in the layout would also take a shape similar to the letter U.

Statistical measure-mean
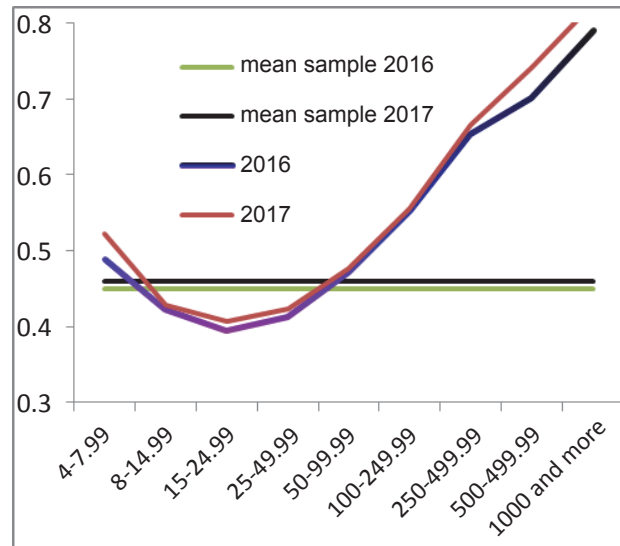

Statistical measure-median

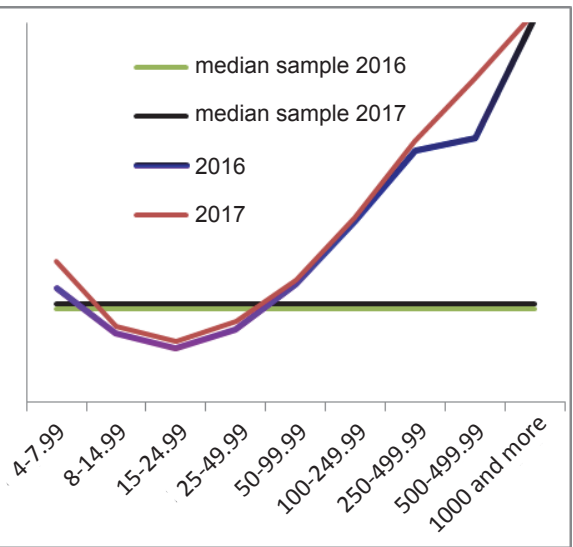

Fig. 2. Technical efficiency in 2016-2017 in groups separated on the basis of economic size - standard income (thous. EUR).

Source: own calculations.

Groups of farms separated on the basis of SO

Table 4

for which differences in technical efficiency distribution

turned out to be statistically insignificant and the median value in 2017

\begin{tabular}{ccc}
\hline \multirow{2}{*}{$\begin{array}{c}\text { Economic size } \\
\text { (thou. EUR) }\end{array}$} & \multicolumn{2}{c}{ Economic size (thou. EUR) } \\
\cline { 2 - 3 } $4-7.99$ & $25-49.99$ & $50-99.99$ \\
\hline $8-14.99$ & 0.351 \\
\hline
\end{tabular}

Source and markings as in Table 3.

Conducted Kruskal-Wallis test allowed the rejection of the null hypothesis on the lack of statistical significance of the differences in the distribution of the technical efficiency indicator in 2016 and 2017 in groups separated on the basis of economic size. ${ }^{4}$ Additional verification allowed to state that there were no statistically

$\overline{{ }^{4} \text { For } 2016 \text { data } \mathrm{H}(8, \mathrm{~N}=12,302)}=2542.840 ; p=0.000$, while for 2017 data $\mathrm{H}(8, \mathrm{~N}=12,293)=2351.604$; $p=0.000$. 
significant differences in the distribution of technical efficiency between farms of economic size up to EUR 8 thous. and EUR 50-99.99 thous. (Table 4). There were also no differences between the group with an economic size of EUR 8-14.99 thous. and medium-small farms (EUR 25-49.99 thous.).

Due to the fact that the production type was taken into consideration as the only grouping feature, there was a significant inter-group differentiation of the technical efficiency distribution (Figure 3). Farms classified as horticultural crops turned out to be the entities with the highest measures of central tendency, followed by farms with granivores (fed predominantly with concentrated feed). Farms with grazing animals and mixed type farms had the lowest level of the indicator. Conducted KruskalWallis tests allowed the rejectinon of the null hypothesis on the lack of statistical significance of the differences in the distribution of the technical efficiency indicator in 2016 and 2017 in groups separated on the basis of this feature. ${ }^{5}$ The Dunn's test showed that the differences between all types were statistically significant.

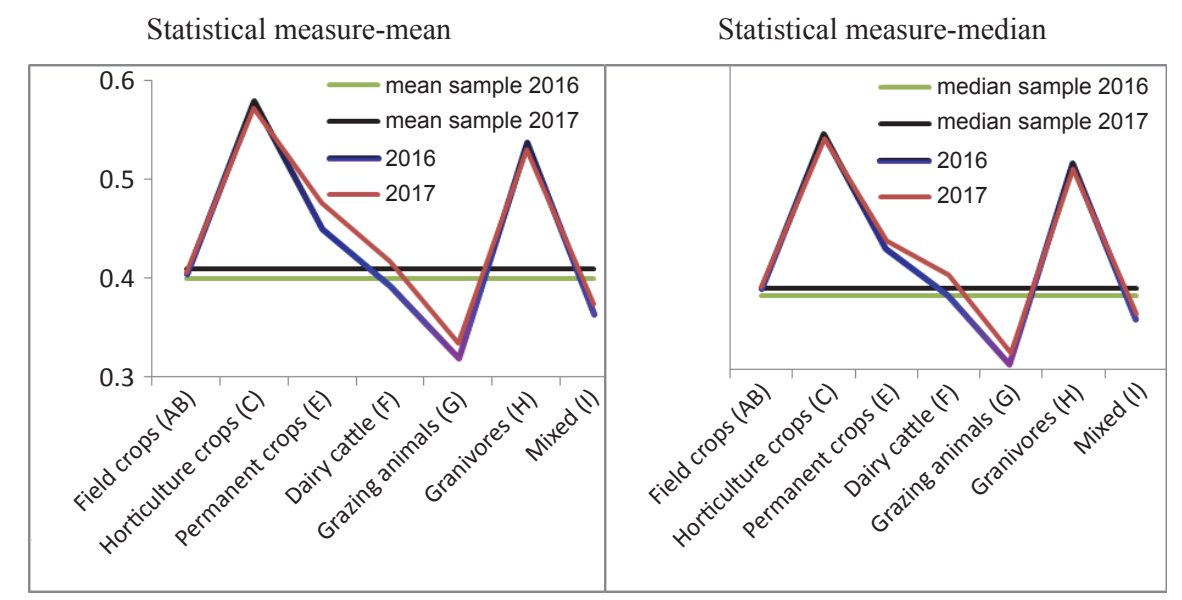

Fig. 3. Technical efficiency in 2016-2017 in groups separated based on the main production type. Source: own calculations.

The analysis of the course of change in technical efficiency in individual production types, taking into account the economic size classes in graphic terms, was significantly diversified (Figures 4-5). ${ }^{6}$ In groups of farms with economic size up to EUR 25 thous., the highest level of the efficiency indicator was recorded by horticulture farms, followed by permanent crops type. The differences between these and other types were statistically significant, except for farms with the size of EUR 15-24.99 thous. where no differences in the distribution between farms with grani-

\footnotetext{
${ }^{5}$ For 2016 data $\mathrm{H}(8, \mathrm{~N}=12,294)=1460.055 ; p=0.000$, while for 2017 data $\mathrm{H}(8, \mathrm{~N}=12,280)=1242.840$; $p=0.000$.

${ }^{6}$ Only those groups for which the condition of the minimum number of objects was met, i.e. 15 , were presented. For this reason, classes with an economic size of EUR 500-999.99 thous. and EUR 1 million and more were also combined in one group.
} 
vores and permanent crops were found. On farms with the economic size of EUR 25-49.99 thous., statistically higher efficiency was confirmed in the case of entities with granivores compared to other groups, except for horticulture farms. In 2016, in classes from EUR 250 thous., the highest technical efficiency was observed on farms with granivores, while in 2017 with dairy cattle. Most interestingly, on farms up to EUR 25 thous. in 2017 and EUR 50 thous. in 2016, technical efficiency in the dairy cattle type was lower than on farms with field crops, and did not differ significantly from mixed farms. However, it was confirmed that farms with grazing animals were the least technically efficient regardless of the economic size of the farm, except for the class of very small farms (up to EUR 8 thous.).

2016

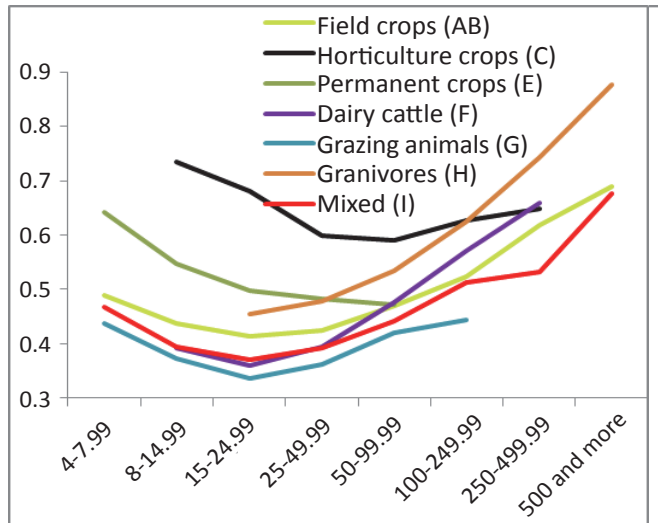

2017

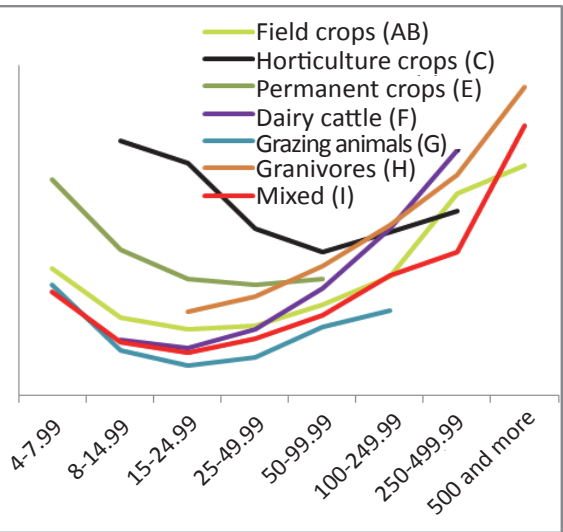

Fig. 4. Average technical efficiency in 2016-2017 in groups separated on the basis of production type and depending on the economic size (thous. EUR).

Source: own calculations.

2016

2017

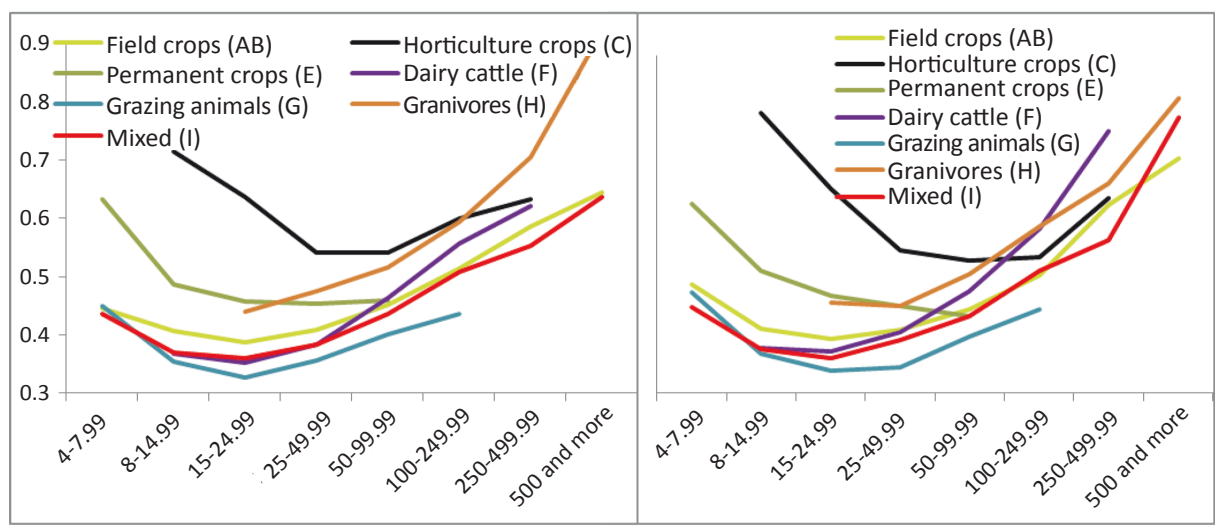

Fig. 5. Technical efficiency (median) in 2016-2017 in groups separated on the basis of production type and depending on the economic size (thous. EUR).

Source: own calculations. 


\section{Summary and conclusions}

Conducted research confirmed theoretical assumptions of Feder and Carter and Kalfayan regarding the relationship between the size of agricultural activity measured by utilised agricultural area and technical efficiency. It was found that these relationships are non-linear and take the $U$ shape in the layout. According to the author, the impact on the deviation from this conclusion observed in research on domestic agriculture could result not only from the choice of the method of measuring productivity, but also from the lack of representativeness for the entire agrarian structure of agriculture.

In 2016-2017 in our country, lower section of the technical efficiency curve was formed by farms with an area of 10 to 30 ha - they were characterised by the lowest level of the indicator. The highest was observed for the smallest farms (0-1.99 ha), and only slightly higher for the largest (1000 ha and more). The differences between the distribution of efficiency in both groups turned out to be statistically insignificant. Therefore, it should be emphasised that in 2016-2017 in terms of technical efficiency, agricultural holdings with both the smallest and the largest area in the country obtained similar results.

The presented graphical curve of the relationship between technical efficiency and utilised agricultural area is similar to the results obtained by Lerman (2002) for data from 2000. However, while there was a convergence of the shape of the curve (both resemble the letter U), in his study by far the most efficient group in Poland were farms with an area of over 100 ha. The indicator for the smallest entities (from 0 to 1 ha) was similar to that of farms with an area of 60-100 ha. However, Lerman studied only individual farms which could have influenced the technical efficiency of the group with the largest area. The impact of the legal form of the farm requires additional research, but it is rather not the main reason for the divergence. The impact of Poland's integration with the European Union and the introduction of more rigorous conditions of production for agricultural holdings and the agri-food industry and other entities trading agricultural raw materials in the country, as well as various types of subsidies seems to be more justified. The impact of these requirements depends on the size of the activity and the level of marketable yield of production, which explains the relative increase in technical efficiency of farms up to 5 ha of utilised agricultural area, i.e. with the lowest level of both features, and a decrease for farms above 100 ha.

The adoption of the standard production value as the measure of the farm size affects the results obtained, however, it does not change the shape of the curve of the technical efficiency dependence in the layout. This was not confirmed empirically due to the exclusion of farms with SO up to EUR 4 thous. from research conducted by Polish FADN. However, it can be assumed with high probability that they are more efficient than economically large farms, at least from groups with standard income not exceeding EUR 100 thousand. 
The graphic shift of the technical efficiency curve in the case of selection of the economic size as an independent variable relative to the utilised agricultural area is a natural consequence of the differences between these features. The economic size measured by the value of standard production causes a different grouping of farms which is the result of, among others, higher production value per unit of area in small and very small farms, i.e. in the research carried out on farms up to 5 ha. Therefore, the choice of the variable illustrating the size of activity in the technical efficiency study may affect the results obtained and their interpretation.

The impact of production orientation (production type) on technical efficiency, taking into account simple relationships (only between these features) clearly indicates decreasing efficiency in the sequence: horticulture farms, granivores, permanent crops, to the group with the lowest indicators of central tendency raising of grazing animal. In this structure, the differences in the distribution of the technical efficiency indicator were confirmed statistically. These conclusions were significantly modified in some cases by additionally taking into account second grouping feature, i.e. economic size class. This was due to the varying shape of the technical efficiency curve in a given type of economic size class presented in the layout in individual production types. Taking into account both grouping features, it was found that horticulture farms showed the highest measures of central tendencies and a statistically significantly different distribution from the other types, but only on farms of economic size up to EUR 100 thous. In groups with an economic size of EUR 250 thous. and more in 2016 the dominance of farms with granivores was observed, while in 2017 in the class of EUR 250-499.99 thous. of dairy cattle farms. The leap of the latter group in 2017 is especially interesting. However, one should bear in mind that the method used is relative and this increase most likely resulted from a combination of several circumstances. One of them was a sharp increase in milk prices in 2017 compared to 2016, felt especially in large and very large entities, relative to the prices of other agricultural raw materials in the country. Due to the use of the value of products expressed in current prices, this allocation change translated into the value of production (effect) also when measuring technical efficiency. However, the observed disturbance did not affect the conclusions.

When assessing the impact of production orientation on technical efficiency, the use of simple dependencies in many cases can lead to erroneous conclusions. Therefore, when examining these relationships, the impact of different distribution of farms in classes of various economic sizes should not be overlooked. 


\section{References}

Ali, D.A., Deininger, K. (2015). Is there a farm size-productivity relationship in African agriculture? Evidence from Rwanda. Land Economics, Vol. 91(2), pp. 317-343.

Alvarez, A., Arias, C. (2004). Technical efficiency and farm size: a conditional analysis. Agricultural Economics, Vol. 30, Issue 3, pp. 241-250.

Ansoms, A., Verdoodt, A., Van Ranst, E. (2008). The inverse relationship between farm size and productivity in rural Rwanda, IOB Discussion Papers 2008.09, Universiteit Antwerpen, Institute of Development Policy and Management.

Bakucs, L.Z., Latruffe, L., Fertő, I., Fogarasi, J. (2010). The impact of EU accession on farms' technical efficiency in Hungary. Post-Communist Economies, Vol. 22, Issue 2, pp. 165-175.

Baležentis, T., Kriščiukaitienė, I., Baležentis, A. (2014). A nonparametric analysis of the determinants of family farm efficiency dynamics in Lithuania. Agricultural Economics, Vol. 45, Issue 5, pp. 589-599.

Barrett, B.C. (1996). On price risk and the inverse farm size-productivity relationship. Journal of Development Economics, Vol. 51, Issue 2, pp. 193-215.

Barrett, B.C., Bellemare, F.M., Hou, Y.J. (2010). Reconsidering Conventional Explanations of the Inverse Productivity-Size Relationship. World Development, Vol. 38, Issue 1, pp. 88-97.

Bhatt, M.S., Bhat S.A., (2014). Technical Efficiency and Farm Size Productivity-Micro Level Evidence from Jammu \& Kashmir. International Journal of Food and Agricultural Economics, Vol. 2, No. 4, pp. 27-49.

Binswanger, H.P., Deininger, K., Feder, G. (1995). Power, distortions, revolt and reform in agricultural land relations. In: J. Behrman, T.N. Srinivasan, T.N. (ed.), Handbook of Development Economics, Vol. HI, Chapter 42, Elsevier, New York.

Binswanger, H.P., Rosenzweig, M.R. (1986). Behavioral and material determinants of production relations in agriculture. Journal of Development Studies, Vol. 22, Issue 3, pp. 503-539.

Bocian, M., Osuch, D., Smolik, A. (2018). Parametry techniczno-ekonomiczne wedtug grup gospodarstw rolnych uczestniczacych w Polskim FADN w 2016 roku. Warszawa: IERiGZ̈-PIB.

Bojneca, Š., Latruffe, L. (2013). Farm size, agricultural subsidies and farm performance in Slovenia. Land Use Policy, Vol. 32, pp. 207-217.

Carter, M.R. (1984). Identification of the inverse relationship between farm size and productivity: an empirical analysis of peasant agricultural production. Oxford Economic Papers, New Series, Vol. 36, No. 1, pp. 131-145.

Chen, Z., Huffman, W.E., Rozelle, S. (2011). Inverse relationship between productivity and farm size: the case of China, Contemporary Economic Policy, Vol. 29, Issue 4, pp. 580-592.

Coelli, T.J., Prasada Rao, D.S.P., O’Donnell, C.J., Battese, G.E. (2005). An introduction to efficiency and productivity analysis. New York: Springer.

Cooper, W.W., Seiford, L.M., Tone, K. (2007). Data envelopment analysis. A comprehensive text with models, applications, references and DEA-Solver Software. Springer.

Cooper, W.W., Seiford, L.M., Zhu, J. (2004). Handbook on data envelopment analysis. Boston: Kluwer Academic Publishers.

Czyżewski, A., Smędzik, K. (2010). Efektywność techniczna i środowiskowa gospodarstw rolnych w Polsce według ich typów i klas wielkości w latach 2006-2008. Roczniki Nauk Rolniczych, Seria G, Vol. 97, Issue 3, pp. 261-273.

Danel, D. (2016). Poziom istotności i granica rozsądku - problem porównań wielokrotnych $\mathrm{w}$ badaniach naukowych na przykładach z zakresu biologii behawioralnej człowieka. In: J. Jakubowski, J. Wątroba (ed.), Zastosowania statystyki i data mining w badaniach naukowych. Kraków: Statsoft Polska. 
De Janvry, A., Sadoulet, E. (2006). Progress in the modeling of rural households' behavior under market failures. In: A. de Janvry, R. Kanbur (ed.), Poverty, Inequality and Development. Essays in Honor of Erik Thorbecke. Part of the Economic Studies in Inequality, Social Exclusion and Well-Being, Vol. 1, Boston: Springer.

Eswaran, M., Kotwal, A. (1985). A Theory of Contractual Structure in Agriculture. The American Economic Review, Vol. 75, Issue 3, pp. 352-367.

Fan, S., Chan-Kang, C. (2005). Is small beautiful? Farm size, productivity, and poverty in Asian agriculture. Agricultural Economics, Vol. 32, Issue 1, pp. 135-146.

Farrell, M.J. (1957). The measurement of productive efficiency. Journal of the Royal Statistical Society. Series A (General), Vol. 120, No. 3, pp. 253-290.

Feder, G. (1985). To relation between farm size and farm productivity: the role of family labor, supervision, and credit constraints. Journal of Development Economics, Vol. 18, pp. 297-313.

Floriańczyk, Z., Płonka, R., Osuch, D. (2017). Wyniki Standardowe 2016 uzyskane przez gospodarstwa rolne uczestniczące w Polskim FADN. Część I. Wyniki Standardowe. Warszawa: IERiGŻ-PIB.

Floriańczyk, Z., Płonka, R., Osuch, D. (2018). Wyniki Standardowe 2017 uzyskane przez gospodarstwa rolne uczestniczace w Polskim FADN. Czesść I. Wyniki Standardowe. Warszawa: IERiGŻ-PIB.

Gautam, M., Ahmed, M. (2019). Too small to be beautiful? The farm size and productivity relationship in Bangladesh. Food Policy, Vol. 84, pp. 165-175.

Goraj, L., Osuch, D., Bocian, M., Cholewa, I., Malanowska, B. (2013). Plan wyboru próby gospodarstw rolnych Polskiego FADN od roku obrachunkowego 2014. Warszawa: IERiGŻ-PIB.

Gorton, M., Davidova, S. (2004). Farm productivity and efficiency in the CEE applicant countries: a synthesis of results. Agricultural Economics, Vol. 30, Issue 1, pp. 1-16.

Helfand, S.M., Taylor, M.P.H. (2018). The Inverse Relationship between Farm Size and Productivity: Refocusing the Debate. No 201811, Working Papers, University of California at Riverside, Department of Economics. Retrieved from: https://EconPapers.repec.org.

Henderson, H., Isaac, A.G. (2017). Modern value chains and the organization of agrarian production. American Journal of Agricultural Economics, Vol. 99, Issue 2, pp. 379-400.

Hockmann, H. (2015). Adjustment costs and efficiency in Polish agriculture: a dynamic efficiency approach. Journal of Productivity Analysis, Vol. 44, Issue 1, pp. 51-68.

Johnson, N.L., Ruttan, V.W. (1994). Why are Farms so Small? World Development, Vol. 22, Issue 5, pp. 691-706.

Kagan, A. (2014). Techniczna i środowiskowa efektywność wielkotowarowych przedsiębiorstw rolnych $w$ Polsce. Warszawa: IERiGŻ-PIB.

Kagin, J., Taylor, J.E., Yúnez-Naude, A. (2016). Inverse Productivity or Inverse Efficiency? Evidence from Mexico, The Journal of Development Studies, Vol. 52, No. 3, pp. 396-411.

Latruffe, L., Balcombe, K., Davidova, S., Zawalińska, K. (2005). Technical and scale efficiency of crop and livestock farms in Poland: does specialisation matter? Agricultural Economics, Vol. 32, No. 3, pp. 281-296.

Lerman, Z. (2002). Productivity and efficiency of individual farms in Poland: A case for land consolidation. Paper presented at the Annual Meeting of the American Agricultural Economics Association, Long Beach, July 28-31 2001.

Marzec, J., Pisulewski, A. (2013a). Ekonometryczna analiza efektywności technicznej farm mlecznych w Polsce na podstawie danych z lat 2004-2011. Roczniki Kolegium Analiz Ekonomicznych, Vol. 30, pp. 255-271. 
Marzec, J., Pisulewski, A. (2013b). Technical efficiency measurement of dairy farms in Poland: an application of bayesian VED model. Metody Ilościowe w Badaniach Ekonomicznych, t. 14 , nr 2, pp. 78-88.

Munroe, D.K. (2001). Economic Efficiency in Polish Peasant Farming: An International Perspective. Regional Studies, Vol. 35, Issue 5, s. 461-471.

Peterson, W., Kislev, Y. (1991). Economies of Scale in Agriculture. A Re-examination of the Evidence. Staff Paper P91-43, Department of Agricultural and Applied Economics, University of Minnesota.

Sen, A.K. (1962). An Aspect of Indian Agriculture, The Economic Weekly, Vol. 14, No. 4-6, pp. 243-246.

Sheng, Y., Zhao, S., Nossal, K., Zhang, D. (2014). Productivity and farm size in Australian agriculture: reinvestigating the returns to scale. Australian Journal of Agricultural and Resource Economics, Vol. 59, Issue 1, pp. 16-38.

Smędzik, K. (2010). Skala produkcji a efektywność różnych typów indywidualnych gospodarstw rolnych w Polsce z zastosowaniem modeli DEA. Roczniki Ekonomiczne Kujawsko-Pomorskiej Szkoty Wyższej, No. 1(3), pp. 261-273.

Srinivasan, T.N. (1972). Farm Size and Productivity Implications of Choice under Uncertainty Source: Sankhyā. The Indian Journal of Statistics, Series B, Vol. 34, No. 4, pp. 409-420.

Sulewski, P. (2008). Powierzchnia użytków rolnych a efektywność gospodarstw rodzinnych. Roczniki Nauk Rolniczych, Seria G, Vol. 94, Issue 2, pp. 130-135.

Syp, A., Kagan, A., Osuch, D. (2018) Efektywność wybranych typów gospodarstw w województwie lubelskim w latach 2014-2016. Roczniki Naukowe SERiA, Vol. 20, Issue 5, pp. 206-211.

Van Zyl, J., Miller, B.R., Parker, A. (1996). Agrarian Structure in Poland. The Myth of LargeFarm Superiority. Policy Research Working Paper, No. 1596. The World Bank. 


\title{
EFEKTYWNOŚĆ TECHNICZNA GOSPODARSTW ROLNYCH W POLSCE \\ W ZALEŻNOŚCI OD ROZMIARÓW DZIAŁALNOŚCI \\ I TYPU PRODUKCYJNEGO
}

\begin{abstract}
Abstrakt
$W$ artykule przedstawiono efektywność techniczna wykorzystania zasobów produkcyjnych dla próby badawczej Polskiego FADN, reprezentującej zbiorowość generalna gospodarstw rolnych, odpowiadajaca za ponad 90\% towarowej produkcji w kraju. Zbadano, jaki wpływ na efektywność wywierają rozmiary działalności mierzone powierzchnia użytków rolnych i standardowa produkcja (wielkościa ekonomiczna) oraz typ produkcyjny. We wszystkich przypadkach stwierdzono nieliniowe zależności, a krzywa efektywności technicznej dla cech grupujacych opartych o rozmiar działalności przyjmowata ksztalt litery U. Obserwowane w licznych badaniach odstępstwa od ksztattu tych zależności moga więc wynikać niejednokrotnie nie tylko z wyboru metody pomiaru, ale również z braku reprezentatywności dla całej struktury agrarnej badanych gospodarstw rolnych. Oceniajac wpływ ukierunkowania produkcyjnego na efektywność techniczna bez uwzglednienia zróżnicowania grup pod względem rozmiarów działalności, zwłaszcza przy zróżnicowanym przyporządkowaniu do odmiennych klas wielkości ekonomicznej, może w wielu przypadkach prowadzić do błędnych wniosków.
\end{abstract}

Słowa kluczowe: rozmiar gospodarstwa rolnego, efektywność techniczna, standardowa produkcja, typ produkcyjny.

Accepted for print: 13.12.2019.

Unless stated otherwise all the materials on the website are available under the Creative Commons Attribution 4.0 International license.

Some rights reserved to the Institute of Agricultural and Food Economics - National Research Institute.

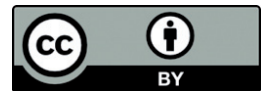

